gr. Biol. Chem., Vol. 30, No. 5, 447 451, 1966]

\title{
Synthesis of Isothiocyanates and their Inhibitory Effects upon Soil Nitrification
}

\author{
By Yoshiro Kinoshita, Noriaki Matsuda, Shin-ichi Sakai, Yasuyoshi Oshima, \\ Togoro Harada and Tsunenori NishiHara* \\ Department of Agricultural Chemistry, Faculty of Agriculture, \\ Kyushu University, Fukuoka \\ *Department of Agricultural Chemistry, Faculty of Agriculture, \\ Kagoshima University, Kagoshima \\ Received October 28, 1965
}

\begin{abstract}
Several isothiocyanates were synthesized and their inhibitory effects upon soil nitrification were examined.

Some aryl isothiocyanates, such as 2,4- and 2,5-dichlorophenyl isothiocyanates, showed high activities.
\end{abstract}

\section{INTRODUCTION}

It is known that most of the nitrogenous ertilizers, such as urea and ammonium alfate, are nitrified to some extent primarily y soil microorganisms and the nitrates so ormed undergo leaching or reductive denitrication. If the nitrification is inhibited by hemical substances, nitrogenous fertilizers vill be utilized better by plants.

Recently, the compounds effective for this urpose have been widely surveyed. J. H. zuastel and P.G. Scholefield pointed out ${ }^{11}$ hat all the five active compounds, namely, thyl carbamate, ethyl N-methylcarbamate, uanidine, methylguanidine, and thiourea, ave a common structure:

\section{R-NH-C-OR or R-NH-C-NH . $_{2}$}

They reported also that other N-nonubstituted or N-monosubstituted carbamates ave the high activities. ${ }^{2}$

We found that several $\mathrm{N}$-monosubstituted

A part of this report was presented at the Annual Meeting $f$ the Agricultural Chemical Society of Japan, Sapporo, uly 20,1964 .

1) J.H. Quastel and P.G. Scholefield, Bact. Revs., 15, 1 1951).

2) J.H. Quastel and P.G. Scholefield, Appl. Microbiology, , 282 (1953). thionocarbamates as well as thioureas are effective, too. ${ }^{3)}$

Nishihara found that $\mathrm{N}$-monosubstituted dithiocarbamates are more effective than N,N-disubstituted ones. ${ }^{4}$ Various dithiocarbamates have long been known to be physiologically active ${ }^{5)}$ and they are widely used also in agriculture as pesticides. Most of these dithiocarbamates are, however, $\mathrm{N}$ alkyl or $\mathrm{N}$-alkylene substituted and not $\mathrm{N}$ aryl derivatives. In a preliminary examination, ${ }^{3)}$ we found that several metal salts of $\mathrm{N}$-phenyldithiocarbamic acid inhibit nitrification seriously; but as might be anticipated, they are unstable and the activities were gradually decreased as they decomposed.

Fungicidal dithiocarbamates are commonly classified into two groups:

(1). N-Non- and N-monosubstituted,

(2). N,N-Disubstituted.

H. L. Klöpping and G. J. M. van der Kerk in 1951, suggested that antifungal action of

3) Y. Kinoshita, A. Kage, Y. Oshima, T. Harada and T. Nishihara, unpublished dada.

4) T. Nishihara, Bull. Fac. Agr. Kagoshima Univ., No. 12, 107 (1962).

5) G. D. Thorn and R. A. Ludwig, "The Dithiocarbamates and Related Compounds," Elsevier, Amsterdam-New York, 1962. 
the former is primarily connected with their conversion to isothiocyanates. ${ }^{6)}$

The fact that there exists a common structure,

\section{$\mathrm{R}-\mathrm{NH}-\mathrm{C}(\mathrm{X})-\mathrm{Y}$}

in the nitrification inhibitors mentioned above, suggests those compounds having the general structure,

$$
\mathrm{R}-\mathrm{N}=\mathrm{C}=\mathrm{X} \text {, }
$$

might also have the inhibitory activities. The present work was carried out to ascertain this possibility.

\section{PREPARATION AND PROPERTIES OF MATERIALS}

Following synthetic methods were adopted.

1. Isothiocyanates

$$
\begin{aligned}
& \text { (A). } \mathrm{R} \cdot \mathrm{NH} \cdot \mathrm{C}(\mathrm{S}) \cdot \mathrm{NH}_{2} \longrightarrow \mathrm{R} \cdot \mathrm{N}=\mathrm{C}=\mathrm{S}+\mathrm{NH}_{3}{ }^{\text {?) }} \\
& \text { (B). } \mathrm{R} \cdot \mathrm{NH} \cdot \mathrm{C}(\mathrm{S}) \cdot \mathrm{SNH}_{4}+\mathrm{MX}_{2} \\
& \left.\longrightarrow \mathrm{R} \cdot \mathrm{N}=\mathrm{C}=\mathrm{S}+\mathrm{NH}_{4} \mathrm{X}+\mathrm{MS}+\mathrm{HX}^{8}\right) \\
& \text { (C). R.NH } \cdot \mathrm{C}(\mathrm{S}) \cdot \mathrm{SNa}+\mathrm{ClCO}_{2} \mathrm{Et} \\
& \rightarrow \mathrm{R} \cdot \mathrm{N}=\mathrm{C}=\mathrm{S}+\mathrm{NaCl}+\mathrm{COS}+\mathrm{EtOH}^{9} \\
& \text { (D). } 2 \mathrm{R} \cdot \mathrm{NH} \cdot \mathrm{C}(\mathrm{S}) \cdot \mathrm{SCH}_{2} \mathrm{CO}_{2} \mathrm{Na}+\mathrm{ZnCl}_{2}+\mathrm{NaOH} \\
& \longrightarrow 2 \mathrm{R} \cdot \mathrm{N}=\mathrm{C}=\mathrm{S}+2 \mathrm{NaCl} \\
& +\mathrm{Zn}\left(\mathrm{SCH}_{2} \mathrm{CO}_{2} \mathrm{Na}\right)_{2}+2 \mathrm{H}_{2} \mathrm{O}^{10}
\end{aligned}
$$

2. Isocyanate

$$
\text { (E). } \mathrm{R} \cdot \mathrm{NH}_{2} \cdot \mathrm{HCl}+\mathrm{COCl}_{2} \rightarrow \mathrm{R} \cdot \mathrm{N}=\mathrm{C}=\mathrm{O}+3 \mathrm{HCl}{ }^{11}
$$

3. Carbodiimide

$$
\text { (F). } \quad \begin{aligned}
& \mathrm{R} \\
& \quad \mathrm{NH} \cdot \mathrm{C}(\mathrm{S}) \cdot \mathrm{NH} \cdot \mathrm{R}+\mathrm{HgO} \\
& \left.\longrightarrow \mathrm{R} \cdot \mathrm{N}=\mathrm{C}=\mathrm{N} \cdot \mathrm{R}+\mathrm{HgS}+\mathrm{H}_{2} \mathrm{O}^{12}\right)
\end{aligned}
$$

Some properties of synthetic compounds are shown in Table I. G. M. Dyson and H. J. George tried to prepare 2,6-dichlorophenyl isothiocyanate by the reaction of 2,6-dichloroaniline and thiophosgen, but obtained only the starting materials. ${ }^{13}$ ) We obtained this sterically hindered isothiocyanate following the method of J. N. Baxter et al.,7) involving pyrolysis of 2,6-dichlorophenyl-thiourea in chlorobenzene. 2,6-

6) H.L. Klöpping and G.J.M. van der Kerk, Rec. trav. chim., 70, 949 (1951); C. A., 46, 5243a (1952).

7) J. N. Baxter, J. Cymerman-Craig, M. Moyle and R.A. White, J. Chem. Soc., I956, 659.

8) F.B. Dains, R.Q. Brewster and C.P. Olander, Org. Synth. Coll. Vol. I, 447 (1956).

9) Maurice L. Moore and Frank S. Crossley, ibid, Coll. Vol. III, 599 (1955).

10) Brit. Pat., 793, 802, Apr. 23, 1958; C. A. 53, 2157e (1959).

11) D. A. Shirley, "Preparation of Organic Intermediates," Jone Wiley and Sons, Inc., 1951, p. 255.

12) T. Hashizume, Yukikagobutsu Goseiho, 13, 22 (1961).

13) G. M. Dyson and H.J. George, J. Chem. Soc., 125, $1702(1924)$.
Table I. Physical Properties of Synthetic CoMPounds

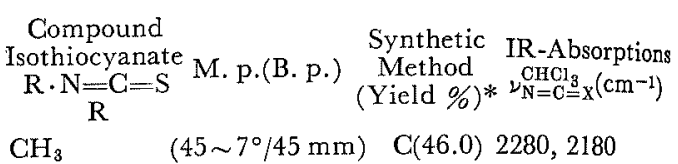

Cyclo- $\mathrm{C}_{6} \mathrm{H}_{11}\left(110 \sim 2^{\circ} / 20 \mathrm{~mm}\right) \mathrm{C}(50.7) 2240,2160,2100$

$\mathrm{C}_{6} \mathrm{H}_{5} \cdot \mathrm{CH}_{2} \quad\left(133 \sim 4^{\circ} / 18 \mathrm{~mm}\right) \mathrm{C}(53.7) 2250,2150$

$\mathrm{C}_{6} \mathrm{H}_{5} \quad\left(120^{\circ} / 35 \mathrm{~mm}\right) \quad \mathrm{B}(72.0) 2230,2140$

$p \cdot \mathrm{CH}_{3} \cdot \mathrm{C}_{6} \mathrm{H}_{4} \quad 26 \sim 7^{\circ} \quad \mathrm{B}(19.0) 2240,2160$

$p-\mathrm{CH}_{3} \mathrm{O} \cdot \mathrm{C}_{6} \mathrm{H}_{4}\left(111 \sim 4^{\circ} / 5 \mathrm{~mm}\right) \mathrm{B}(10.4) 2240,2160$

$p-\mathrm{F} \cdot \mathrm{C}_{6} \mathrm{H}_{4} \quad 23 \sim 5^{\circ} \quad$ A( 8.4) 2220,2140

$o-\mathrm{Cl} \cdot \mathrm{C}_{6} \mathrm{H}_{4} \quad\left(160^{\circ} / 42 \mathrm{~mm}\right) \quad \mathrm{A}(47.3) 2230,2090$

$m-\mathrm{Cl} \cdot \mathrm{C}_{6} \mathrm{H}_{4} \quad\left(158^{\circ} / 60 \mathrm{~mm}\right) \quad \mathrm{D}(46.0) 2250,2150$

$p$ - $\mathrm{Cl} . \mathrm{C}_{6} \mathrm{H}_{4} \quad 43 \sim 5^{\circ} \quad \mathrm{D}(54.0) 2230,2140$

$p-\mathrm{Br} \cdot \mathrm{C}_{6} \mathrm{H}_{4} \quad 56 \sim 8^{\circ} \quad \mathrm{A}(70.2) 2250,2160$

$p$-I. $\mathrm{C}_{6} \mathrm{H}_{4} \quad 75 \sim 6^{\circ} \quad \mathrm{A}(55.0) 2250,2160$

$2,3-\mathrm{Cl}_{2} \mathrm{C}_{6} \mathrm{H}_{3}\left(166^{\circ} / 28 \mathrm{~mm}\right) \quad \mathrm{A}(5 \mathrm{l} .2) 2290,2090$

$2,4-\mathrm{Cl}_{2} \mathrm{C}_{6} \mathrm{H}_{3} \quad 41 \sim 2^{\circ} \quad \mathrm{A}(68.6) 2270,2080$

$2,5-\mathrm{Cl}_{2} \mathrm{C}_{6} \mathrm{H}_{3}\left(125^{\circ} / 3 \mathrm{~mm}\right) \quad \mathrm{A}(80.2) 2260,2090$

$2,6-\mathrm{Cl}_{2} \mathrm{C}_{6} \mathrm{H}_{3} \quad 42 \sim 3^{\circ} \quad \mathrm{A}(72.2) 2270,2080$

$3,4-\mathrm{Cl}_{2} \mathrm{C}_{6} \mathrm{H}_{3}\left(168^{\circ} / 33 \mathrm{~mm}\right) \quad \mathrm{A}(16.7) 2260,2080$

$3,5-\mathrm{Cl}_{2} \mathrm{C}_{6} \mathrm{H}_{3} \quad 44 \sim 6^{\circ} \quad \mathrm{A}(16.0) 2300,2090,1990$

Isocyanate

Carbodiimide

$\mathrm{R} \cdot \mathrm{N}=\mathrm{C}=\mathrm{O}$

$\mathrm{R}$

$\mathrm{C}_{6} \mathrm{H}_{5} \quad(158 \sim 65 \% / 760 \mathrm{~mm}) \mathrm{E}(75.5) 2320,2280,2240$

$\mathrm{R} \cdot \mathrm{N}=\mathrm{C}=\mathrm{N} \cdot \mathrm{R}$

$\mathrm{R}$

Cyclo- $\mathrm{C}_{6} \mathrm{H}_{1 \mathrm{I}}\left(142 \sim 3^{\circ} / 9 \mathrm{~mm}\right) \quad \mathrm{F}(70.0) 2130$

* (A): from thiourea, (B): from amine, (C): from amine

(D): from amine, (E): from amine, (F): from thiourea

Dichlorophenyl-thiourea was prepared modifying the method reported by R. L. Frank and P. V. Smith. ${ }^{14\}}$

2,6-Dichlorophenylthiourea. To a hot solution of anhydrous ammonium thiocyanate $(13 \mathrm{~g})$ in $300 \mathrm{ml}$ of dry acetone, was added dropwise $21.2 \mathrm{~g}$ of benzoyl chloride. After the reaction had subsided, a solution of 2,6-dichloroaniline $\left.{ }^{15}\right)(24.3 \mathrm{~g})$ in $200 \mathrm{ml}$ of dry acetone was gradually added. With occassional swirling the mixture was refluxed for one hour. A half of the solvent was evaporated and the residue was poured into 21 of water. The resulting yellow precipitate was separated by filtration. The crystalline 1-benzoyl-3-(2,6-dichlorophenyl)thiourea was saponified with a boiling solution of $250 \mathrm{~g}$ of $10 \%$

14) R.L. Frank and P.V. Smith, Org. Synth. Coll. Vol. III, 735 (1955).

15) Margaret K. Seikel, ibid., Coll. Vol. III, 262 (1955). 


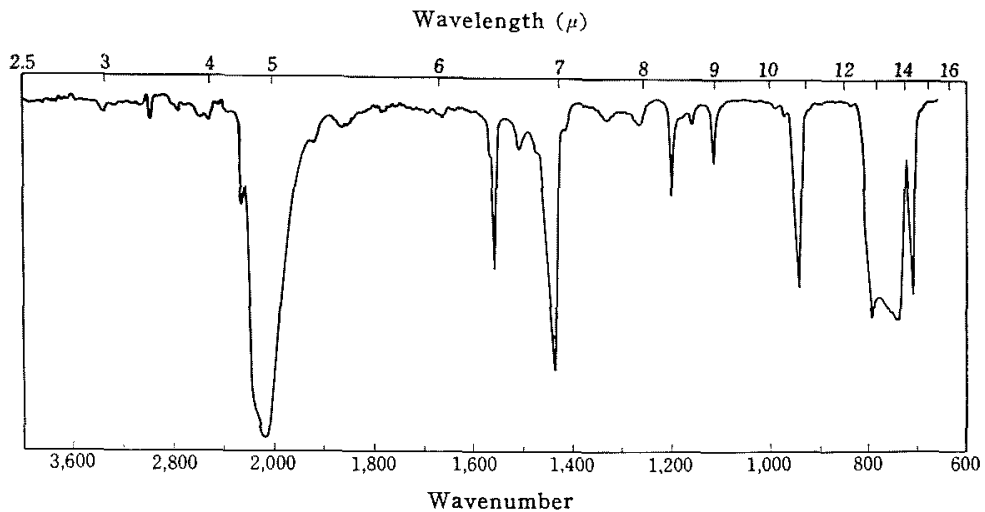

FIG. 1. IR Absorption Spectrum of 2,6-Dichlorophenyl Isothiocyanate $\left(10 \% \mathrm{CHCl}_{3}\right.$ Sol.)

odium hydroxide. After cooling, the solution was cidified with concentrated hydrochloric acid to recipitate both benzoic acid and 2,6-dichlorophenylhiourea, and then made alkaline with ammonium lydroxide to dissolve benzoic acid. 2,6-Dichlorohenylthiourea was filtered and recrystallized from thanol. Yield, $20.0 \mathrm{~g}(60.3 \circ)$. o. m.p. $156 \sim 158^{\circ} \mathrm{C}$. inal. Found: C, 38.36; H, 2.82; N, 12.73. Calcd. for ${ }_{7} \mathrm{H}_{6} \mathrm{~N}_{2} \mathrm{Cl}_{2} \mathrm{~S}: \mathrm{C}, 38.02 ; \mathrm{H}, 2.74 ; \mathrm{N}, 12.67 \%$.

2,6-Dichlorophenyl isothiocyanate. A solution if 2,6-dichlorophenylthiourea $(18 \mathrm{~g})$ in $250 \mathrm{ml}$ of hlorobenzene was refluxed for ten hours. The solvent vas evaporated under reduced pressure and the esidue was extracted with three $100-\mathrm{ml}$ portions of thexane. The combined extract was evaporated and he residue was distilled under reduced pressure. The olidified distillate was crystallized from $n$-hexane. kield, $12.0 \mathrm{~g}(72.2 \%)$. m.p. $42 \sim 43^{\circ} \mathrm{C}$. Anal. Found: , 41.49; H, 1.55; N, 6.82. Calcd, for $\mathrm{C}_{7} \mathrm{H}_{3} \mathrm{NCl}_{2} \mathrm{~S}$ : $\lambda, 41.20 ; \mathrm{H}, 1.48 ; \mathrm{N} 6.86 \%$. Infrared absorption pectrum of this compound is shown in Fig. 1.

Derivative. Refluxing a mixture of 2,6-dichlorohenyl isothiocyanate $(3.5 \mathrm{~g})$ and excess methanol for wenty hours afforded methyl N-(2,6-dichlorophenyl) hionocarbamate. Yield, $3.0 \mathrm{~g}(74.1 \%)$. m.p. $149^{\circ} \mathrm{C}$ from $\mathrm{MeOH}$ ). Anal. Found: $\mathrm{C}, 40.71 ; \mathrm{H}, 3.07 ; \mathrm{N}$, i.95. Calcd. for $\mathrm{C}_{8} \mathrm{H}_{2} \mathrm{NCl}_{2} \mathrm{OS}: \mathrm{C}, 40.69 ; \mathrm{H}, 2.99$; J, $5.93 \%$.

\section{BIOASSAY METHOD}

A soil of definite physical and chemical condi-

16) T. Harada, Y. Oshima, T. Nishihara and Y. Kinoshita, ?. Sci. Soil and Manure, Japan. (Nippon Dojohiryogaku lasshi) 35, 392 (1964).

tions, 16$) 25 \mathrm{mg}$ of urea-nitrogen per $100 \mathrm{~g}$ of an airdry soil, and an inhibitor of indicated concentration were thoroughly mixed in a jar. The jar was incubated at $30^{\circ} \mathrm{C}$ for two weeks. The soil was analyzed for ammonium, nitrite, and nitrate nitrogens by the previous method.16) (The conversion of urea to ammonium nitrogen was not seriously prevented by any of the compounds used.)

In this paper, we showed the Inhibition Index (I) which is calculated by the following equation:

$$
\mathrm{I}=100(A-B) / 25
$$

wherein $A$ represents $\mathrm{mg}$ of $\mathrm{NH}_{4}-\mathrm{N}$ per $100 \mathrm{~g}$ of dry soil containing the inhibitor, $B$ represents $\mathrm{mg}$ of $\mathrm{NH}_{4}-\mathrm{N}$ per $100 \mathrm{~g}$ of dry soil without the inhibitor.

\section{RESULTS AND DISCUSSION}

Table Il shows the activities of six com-

TABle II. EFFECTS OF SIX Compounds Having The General Structure, $\mathrm{R}-\mathrm{N}=\mathrm{C}=\mathrm{X}$.

Compound

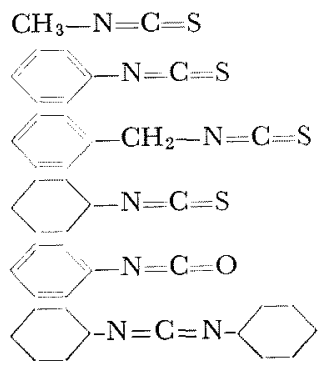

M. W.

78.120

135.191

149.218

141.239

119.125

206.335
(I)

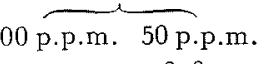
3.6 $91.6 \quad 53.6$

$44.4 \quad 28.0$

$73.2 \quad 38.0$

0.0

$16.8 \quad 0.0$ 
pounds having the general structure, $\mathrm{R}-\mathrm{N}=$ $\mathrm{C}=\mathrm{X}$. Three isothiocyanates other than methyl isothiocyanate exhibited moderate inhibitory activities, whereas phenyl isocyanate and dicyclohexylcarbodiimide showed little or no activities.

It was postulated that fungicidal dithiocarbamates or their breakdown products, such as isothiocyanates, combine with the sulfhydryl groups of essential enzymes ${ }^{17)}$ in the fungal cell system or with those of some constituents $^{18)}$ of the cell membranes.

Though having similar chemical properties with isothiocyanates, phenyl isocyanate and dicyclohexylcarbodiimide were practically inactive possibly because of their instability under the experimental condition.

As phenyl isothiocyanate showed the highest activity of the four isothiocyanates, we compared the activities of some aryl isothiocyanates (Table III).

TABLE III. EFFECTS OF ARYL IsOThIOCYANATES

\begin{tabular}{lrrrr} 
Compound & \multicolumn{3}{c}{$\mathrm{X}$} \\
$\quad$ M. W. & $\begin{array}{c}\text { Hammett } \sigma \\
\text { Constant } \\
\text { of } \mathrm{X}^{19)}\end{array}$ & 50 p.p.m. & 20 p.p.m. \\
$\mathrm{CH}_{3} \mathrm{O}-$ & 165.218 & -0.268 & 63.2 & 33.2 \\
$\mathrm{CH}_{3}-$ & 149.218 & -0.170 & 57.6 & 10.8 \\
$\mathrm{H}-$ & 135.191 & 0.000 & 53.6 & 8.4 \\
$\mathrm{~F}-$ & 153.183 & +0.062 & 80.0 & 28.8 \\
$\mathrm{Cl}-$ & 169.640 & +0.227 & 81.6 & 52.4 \\
$\mathrm{Br}-$ & 214.099 & +0.232 & 72.0 & 48.0 \\
$\mathrm{I}-$ & 261.093 & +0.276 & 52.4 & 38.8
\end{tabular}

In considering the relationship between the chemical structure and the inhibitory activity, it must be taken into consideration that the bioassay was not conducted with same molar concentrations but with same weight concentrations.

Generally, the larger the Hammett $\sigma$ constant of the group $\mathrm{X}$ introduced into

17) Kaars Sijpesteijn, A. and G.J.M. van der Kerk, Biochim. Biophys. Acta, 13, 545 (1954).

18) R. T. Wedding and J.B. Kendrick, Jr., Phytopathology, 49, $557(1959)$.

19) Robert W. Taft, Jr., in M.S. Newman. "Steric Effects in Organic Chemistry," Wiley, New York, 1956, p. 571. benzene ring is, the more electrophilic the isothiocyanate becomes. ${ }^{20)}$ But there is no complete parallel between the inhibitory activity and the electrophilicity of the compound. (cf. ref. 20). These results are not surprising, considering that fungicidal activity of a compound may be decided not only by chemical reactivity but stability, permeability into fungal cell, steric factor of the compound and other environmental factors.

Despite of marked increase in atomic weight in the order, $\mathrm{F}<\mathrm{Cl}<\mathrm{Br}<\mathrm{I}$, the inhibitory activities of $p$-halophenyl isothiocyanates at same concentrations were not altered considerably. These data suggest that the inhibitory activities of halophenyl isothiocyanates are more or less associated with their electrophilic strength.

Of these compounds in Table III, $p$-chlorophenyl isothiocyanate showed the highest activity. We, therefore, examined the effects of the three isomers of chlorophenyl isothiocyanate. (Table IV). The activities of these compounds were too high to be graded this time.

TABLE IV. EFFECTS OF ChLOROPHENYL ISOTHIOCYANATES

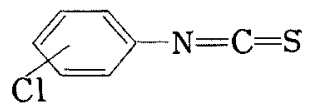

Compound

$$
\text { 2-Cl }
$$

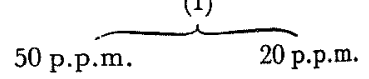

3-Cl

95.2

94.8

4-Ci

97.2

96.4

95.2

91.6

Table $\mathrm{V}$ shows the activities of all the six dichlorophenyl isothiocyanates. 2,4-Dichlorophenyl and 2,5-dichlorophenyl isothiocyanates exhibited the high activities; but four other compounds showed rather low activities.

If fungicidal isothiocyanates react, as mentioned above, with nucleophiles, such as sulfhydryl groups of essential enzymes, the 20) D. W. Browne and G. M. Dyson, J. Chem. Soc., 1931,
3285 . 
TABLE V. EFFECTS OF DICHLOROPHENYL ISOTHIOCYANATES<smiles>S=C=Nc1ccc(Cl)cc1</smiles>

Compound

$$
2,3-\mathrm{Cl}_{2}
$$

$2,4-\mathrm{Cl}_{2}$

Exp. (a) $2,5-\mathrm{Cl}_{2}$

$2,6-\mathrm{Cl}_{2}$

$3,4-\mathrm{Cl}_{2}$

$3,5-\mathrm{Cl}_{2}$

* Data from Exp. (b)

20 p.p.m. 10 p.p.m. 5 p.p.m.

Exp. (b) $\begin{array}{rrrr}2,4-\mathrm{Cl}_{2} & 89.6 & 83.2 & 40.8 \\ 2,5-\mathrm{Cl}_{2} & 90.8 & 88.8 & 54.4\end{array}$

approach and the subsequent combination of these reactants may be largely influenced by the steric factors. This possibility was supported by the data of Table V.

Recently, Omura found that 2,5-dichlorophenyl isothiocyanate actually inhibits the cell-free ammonia-oxidizing enzymes system of chicken liver. ${ }^{21)}$
The data of Tables III and IV apparently show that different tests sometimes give varying results because the nitrifying abilities of the soil microorganisms differ from one test to another. We, therefore, compared the activities of 4-chlorophenyl and 2,5-dichlorophenyl isothiocyanates at the same time. (Table VI).

\section{TABLE VI. COMPaRison OF THE ACtivities OF 4-CHLOROPHENYL AND 2,5-DICHLOROPHENYL ISOTHIOCYANATES}

\begin{tabular}{|c|c|c|c|c|}
\hline \multirow{2}{*}{ Compound } & \multicolumn{3}{|c|}{ (I) } & \\
\hline & $\begin{array}{c}\text { 30p.p.m. } \\
67.2\end{array}$ & $\begin{array}{c}20 \text { p.p.m. } \\
55.6\end{array}$ & 10p.p.m. & $\begin{array}{c}\text { 5p.p.m. } \\
16.8\end{array}$ \\
\hline $2,5-\mathrm{Cl}_{2}$ & 88.4 & 87.6 & 86.4 & 47.2 \\
\hline
\end{tabular}

2,5-Dichlorophenyl isothiocyanate was found to be the most active compound of all the isothiocyanates examined.

Acknowledgement The authors wish to express their sincere thanks to Mr. Arimichi Kage for his tecnical assistance.

\footnotetext{
21) H. Omura, Personal Communication.
} 